\title{
Placobdella costata an Ectoparasite for Mauremys caspica in North of Iran
}

\section{Nasim Bashirichelkasari ${ }^{1}$ and Reza Yadollahvandmiandoab ${ }^{2 *}$}

${ }^{1}$ Department of Biology, Faculty of Sciences, Golestan University, Gorgan, Iran

${ }^{2}$ Department of Systematics and Ecology- DSE, Center for Exact and Natural Sciences- CCEN, Federal University of Paraíba, UFPB, Cidade Universitária, João Pessoa, $P B$, Brazil

\section{Short Communication}

The Mauremys caspica (Gmelin, 1774) belongs to the Geoemydidae family, is a medium-sized freshwater turtle that is widespread throughout the Middle East. In Iran, the species is widely distributed in Golestan, Mazandaran, Guilan, Ardebil, East and West Azarbaijan, Kurdistan, Kermanshah, Lorestan, Ilam, Khuzestan and Fars provinces. Despite the species is still common in many parts of its range, landscape alteration, parasites, pollution and intensification of water management in Turkey, Syria, Iraq and Iran are increasingly threatening the survival of many populations.

The Mauremys caspica (Gmelin, 1774) belongs to the Geoemydidae family, is a medium-sized freshwater turtle that is widespread throughout the Middle East [1]. In Iran, the species is widely distributed in Golestan, Mazandaran, Guilan, Ardebil, East and West Azarbaijan, Kurdistan, Kermanshah, Lorestan, Ilam, Khuzestan and Fars provinces [2]. Despite the species is still common in many parts of its range, landscape alteration, parasites, pollution and intensification of water management in Turkey, Syria, Iraq and Iran are increasingly threatening the survival of many populations [1]. The order Hirudinida was traditionally divided into two suborders, the Rhynchobdellida, in which leeches have a protrusible proboscis, and the Arhynchobdellida, in which leeches lack a proboscis. The Rhynchobdellida included three families: Ozobranchidae, Glossiphoniidae, and Piscicolidae [3]. Leeches can cause bacterial and fungal infections and anemia in captive hosts, being also vectors for hemoparasites [4]. Whereas most leeches of the genus Placobdella (Hirudinida: Glossiphoniidae) have mainly been recorded on fish, amphibians, crocodiles and turtles, Placobdella costata primarily feeds on the blood of freshwater turtles [5,6], but may facultatively feed on the blood of birds and mammals [7]. According to [8], P. costata is the only Palaeartic leech that feeds on reptilian blood, and mainly on E. orbicularis; in some parts of its distribution area (Asia) it attacks $M$. caspica. Currently, P. costata is a widely distributed leech in the European Mediterranean area. It occurs from the Iberian Peninsula to the Balkan Peninsula and the Black Sea coast [6]. It is also ranges from Morocco to Iran and the northern Caucasus [9]. Whereas other species of Placobdella leeches have been observed feeding from the blood sinuses of the plastron and carapace bones of turtles [10], $P$. costata are usually attached to the neck and groin regions, where the skin is thin and unarmoured, or in the middle part of the plastron [6,11]. Life cycle of $P$. costata has not been studied completely, some information was reported by [12] and [13]. In temperate climates, it reproduces in the summer. In addition, individuals with developing embryos or young were found only outside the hosts [13].

We found five specimens of $P$. costata on three $M$. caspica in Golestan (Agghala city) and Mazandaran (Noor and Babolsar cities) provinces (Figure 1). Specimens were identified based on identification key for family Glossiphoniidae [14]. The biggest specimen has $26 \mathrm{~mm}$ of length and smallest $7 \mathrm{~mm}$. Specimens were connected to the end part of limbs and under tail close to cloaca that have thinner skin. The body of $P$. costata is flat and long. The dorsal surface is convex and ventral surface is somewhat concave. The eyes are situated on segment III. The colour of the body is olive-green and brownish (Figure 2). The dorsal surface has

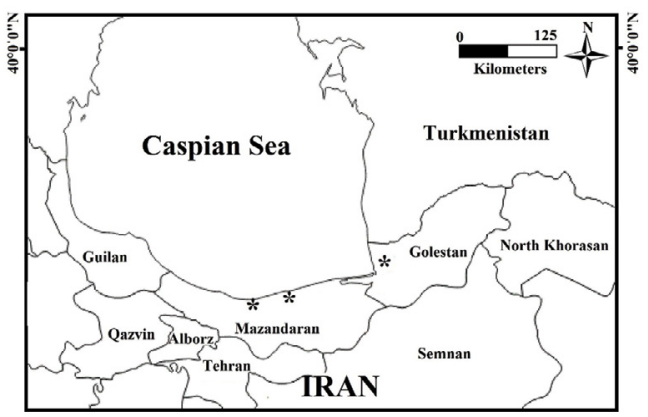

Figure 1: Map of sampling localities for $P$. costata in northern Iran.

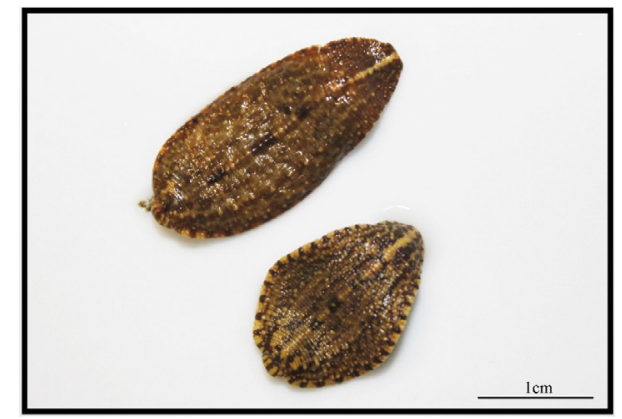

Figure 2: Dorsal surface of $P$. costata, separated from $M$. caspica, Noor, Iran.

numerous papillae in six longitudinal rows of yellow spots. The mouth pore is located near the anterior rim of the oral sucker. Anyway, we found and report the presence of $P$. costata on M. caspica in this area.

\section{Acknowledgment}

We wish to thank Prof. Daniel Oliveira Mesquita from Universidade Federal da Paraíba and Prof. Haji Gholi Kami from Golestan University for scientific and technical supports.

\section{References}

1. Vamberger MH, Stuckas H, Ayad D, Gracia E, Aloufi AA (2013) Conservation genetics and phylogeography of the poorly known Middle Eastern terrapin Mauremys caspica (Testudines: Geoemydidae). Org Divers Evol 13: 77-85.

*Corresponding author: Reza Yadollahvandmiandoab, Department of Systematics and Ecology- DSE, Center for Exact and Natural Sciences - CCEN Federal University of Paraíba, UFPB, Cidade Universitária, João Pessoa, PB, Brazil, Tel: +55 83 3216-7200; E-mail: Rezayadollahvand.tmu@gmail.com

Received September 08, 2017; Accepted September 28, 2017; Published September 30, 2017

Citation: Bashirichelkasari N, Yadollahvandmiandoab R (2017) Placobdella costata an Ectoparasite for Mauremys caspica in North of Iran. J Aquac Res Development 8: 506. doi: 10.4172/2155-9546.1000506

Copyright: (c) 2017 Bashirichelkasari N, et al. This is an open-access article distributed under the terms of the Creative Commons Attribution License, which permits unrestricted use, distribution, and reproduction in any medium, provided the original author and source are credited. 
Citation: Bashirichelkasari N, Yadollahvandmiandoab R (2017) Placobdella costata an Ectoparasite for Mauremys caspica in North of Iran. J Aquac Res Development 8: 506. doi: 10.4172/2155-9546.1000506

Page 2 of 2

2. Kami HG, Hojati V, Pashaee M (2006) A biological study of the European pond turtle, Emys orbicularis persica, and the Caspian pond turtle, Mauremys caspica caspica, in the Golestan and Mazandaran provinces of Iran. Zool Middle East 37: 21-28.

3. Burreson EM, Allen DM (1978) Morphology and biology of Mysidobdella borealis (Johansson) Comb. N. (Hirudinea: Piscicolidae), from mysids in the western north Atlantic. J Parasitol 64: 1082-1091.

4. Readel AM, Philps CA, Wetzel MR (2008) Leech parasitism in a turtle assemblage: Effects of host and environmental characteristics. Copeia 1: 227233.

5. Sket B, Trontelj P (2008) Global diversity of leeches (Hirundinea) in freshwater. Hydrobiologia 595: 129-137.

6. Bielecki A, Cichocka JM, Jablonski A, Jelen I, Ropelewska E, et al (2012) Coexistence of Placobdella costata (Fr. Muller, 1846) (Hirudinida: Glossiphoniidae) and mud turtle Emys orbicularis. Biologia 67: 1-8.

7. Sapkarev JA (1964) Faunata na Hirudinea wo Makedonija. Folia Balcan 3: 1-8.
8. Lukin El (1976) Pijavki presnych i solonovatich vodojemov. Fauna USSR. Pijavki. Academy of Science of the USSR, Leningrad, UK.

9. Saglam N (2001) First record of the leech Placobdella costata (Hirudinoidea: Glossiphoniidae) in Turkey. Zool Middle East 23: 113-118.

10. Siddall ME, Gaffney E (2004) Observations on the Leech Placobdella ornate feeding from bony tissues of turtles. J Parasitol 90: 1186-1188.

11. Ayres C, Alvarez A (2008) On the presence of Placobdella sp. leeches on Emys orbicularis. Acta Biol Univ Daugavp 8: 53-55.

12. Wilkialis $\mathrm{J}$ (1973) The biology of nutrition in Haementeria costata (Fr. Müller, 1846). Zool Pol 23: 213-225.

13. Sawyer RT (1986) Leech biology and behaviour. Oxford University Press, NY, USA.

14. Soo's A (1969) Identification key to the leech (Hirudinoidea) genera of the world, with a catalogue of the species. VI. Family: Glossiphoniidae. Acta Zool Acad Sci Hung 15: 397-454. 